Research Article

\title{
Tulsi (Ocimum sanctum) Leaf Ethanol Extract Reduces Inflammatory Cell Infiltration in Aspirin-Induced Gastritis Rats
}

\section{Ekstrak Etanol Daun Kemangi (Ocimum sanctum) Menurunkan Infiltrasi Sel Radang pada Tikus Gastritis yang Diinduksi Aspirin}

\author{
Festi Artika S, Willy Sandhika', Tri Hartini Yuliawati ${ }^{3}$ \\ ${ }^{1}$ Medical Study Program Faculty of Medicine Universitas Airlangga Surabaya \\ ${ }^{2}$ Department of Anatomical Pathology Faculty of Medicine Universitas Airlangga Surabaya \\ ${ }^{3}$ Department of Anatomy and Histology Faculty of Medicine Universitas Airlangga Surabaya
}

\begin{abstract}
Gastritis is an inflammation of the gastric mucosa. Tulsi leaf extract has phenol, flavonoid and saponin compounds which are potential as antioxidant and increase defensive factors in the gastric. The purpose of this research was to find out the effect of tulsi (Ocimum sanctum) leaf extract in polymorphonuclear (PMN) inflammatory cell infiltration in gastric of aspirin-induced gastritis rat model. This study was laboratory experimental research using post-test only control group design. Randomly, 27 male rats were divided into 3 groups, the first group was not induced by aspirin and extract as negative control, the second group was induced by aspirin of $600 \mathrm{mg} / \mathrm{kgBW}$ as positive control, and the third group was induced by aspirin of $600 \mathrm{mg} / \mathrm{kgBW}$ and was given Ocimum sanctum extract at a dose of $400 \mathrm{mg} / \mathrm{kgBW}$ as treatment group. Gastric of the rats were taken on $16^{\text {th }}$ day for histopathology evaluation using hematoxylin and eosin (HE) staining. Evaluation was done by calculating the PMN inflammatory cell infiltration in mucosal and submucosal layer. The results of the average number of PMN inflammatory cell in the gastric tissue of the treatment group showed a significant decrease compared to the positive and negative control groups with $P$-value $<0.05$. This study proved that Ocimum sanctum leaf extract administration with the dose of $400 \mathrm{mg} / \mathrm{kgBW}$ can decrease gastritis inflammation by reducing PMN inflammatory cell in gastric of aspirin-induced gastritis rat model.
\end{abstract}

Keywords: Aspirin, gastritis, inflammatory cells, Ocimum sanctum

\section{ABSTRAK}

Gastritis adalah suatu inflamasi yang terjadi pada mukosa lambung. Ekstrak daun kemangi (Ocimum sanctum) memiliki kandungan senyawa fenol, flavonoid, dan saponin yang berpotensi sebagai antioksidan dan meningkatkan faktor defensif pada lambung. Penelitian ini bertujuan untuk mengetahui pengaruh ekstrak daun kemangi (Ocimum sanctum) terhadap infiltrasi sel radang polimorfonuklear (PMN) pada lambung tikus yang mengalami gastritis akibat induksi aspirin. Penelitian ini adalah penelitian eksperimental laboratorium dengan metode post-test only group control design. Dua puluh tujuh tikus jantan dibagi secara acak dalam 3 kelompok, yaitu kelompok tanpa diberi aspirin dan ekstrak sebagai kontrol negatif, kelompok yang diinduksi aspirin dosis $600 \mathrm{mg} / \mathrm{kgBB}$ sebagai kontrol positif, dan kelompok yang diinduksi aspirin dosis $600 \mathrm{mg} / \mathrm{kgBB}$ dan diberi ekstrak Ocimum sanctum dosis $400 \mathrm{mg} / \mathrm{kgBB}$ sebagai kelompok perlakuan. Pada hari ke-16 dilakukan pengambilan lambung untuk penilaian histopatologi menggunakan pewarnaan hematoksilin dan eosin (HE). Evaluasi dilakukan dengan menghitung infiltrasi sel radang PMN pada lapisan mukosa dan submukosa. Hasil rata-rata jumlah infiltrasi sel radang pada jaringan lambung kelompok perlakuan menunjukkan penurunan yang bermakna dibanding dengan kelompok kontrol positif dan kontrol negatif dengan nilai $\mathrm{P}<0,05$. Penelitian ini membuktikan bahwa pemberian ekstrak daun Ocimum sanctum dosis $400 \mathrm{mg} / \mathrm{kgBB}$ dapat menurunkan derajat inflamasi gastritis dengan penurunan rata-rata jumlah infiltrasi sel radang PMN pada lambung model tikus gastritis.

Kata Kunci: Aspirin, gastritis, Ocimum sanctum, sel radang

Correspondence: Festi Artika S. Medical Study Program Faculty of Medicine Universitas Airlangga Surabaya, Jl. Mayjen Prof. Dr. Moestopo No.47Surabaya, Jawa Timur Tel.081357662154 Email:festi.artika.sari-2016@fk.unair.ac.id

DOI: http://dx.doi.org/10.21776/ub.jkb.2020.031.01.10 


\section{INTRODUCTION}

Gastritis is an inflammatory disease that happens in the gastric mucosa (1). Based on World Health Organization (WHO) data in 2012, the prevalence of gastritis in the world is around 1.8-2.1 million people every year. The prevalence of gastritis in Southeast Asia is about 583,635 people each year (2). The high incidence of gastritis is an issue that needs attention. Gastritis that occurs in the long run will turn into chronic gastritis. Chronic inflammation can cause damage to the gastric mucosa and become atrophy. This causes gastric mucosal dysfunction and disruption of stomach acid production. Severe atrophy gastritis has a high risk of cancer and perforation (3).

Herbal medicine has been used to treat gastric disease for a long time ago. Several studies have shown that herbal treatments are effective in treating gastric disease in humans and animal models that induced by nonsteroidal anti-inflammatory drugs (NSAIDs), ethanol, cold-restraint stress, and pylorus ligation. Herbal medicine is comparable or even more effective than drugs such as omeprazole or cimetidine. Herbal medicine also has more minimal side effects. The mechanism of herbal medicine in treating gastric ulcers is by stimulation of mucous cell proliferation, anti-oxidation, and inhibition of gastric acid secretion as well as $\mathrm{H}(+) / \mathrm{K}(+)$-ATPase activity (4).

The phytochemical compounds of Ocimum sanctum leaves such as flavonoids, phenolics and saponins play a role in gastritis healing process. These chemical contents have the potential to support the gastritis healing process by inhibiting the offensive acid pepsin secretion, lipid peroxidation and histamine antagonistic, also increasing the gastric defensive factors like mucin secretion, cellular mucus and lifespan of mucosal cells, as well as antioxidant activity $(5,6)$. Therefore, it is necessary to conduct research to determine the potential of Ocimum sanctum leaf extract as an alternative therapy for gastritis using an aspirin-induced rat animal model with an evaluation of the degree of inflammation assessed from the average amount of inflammatory cell infiltration in the mucosal and submucosa layer.

\section{METHOD}

\section{Animal Model}

This research was an experimental laboratory study with post-test only control design. The research used 27 rats (Rattus norvegicus) with inclusion criteria, i.e., male, 150200 grams body weight, 3-5 months old, and having physical health characterized by move actively and has smooth, clean fur and no fleas in the body. The exclusion criteria of rats were those that died during the study. This study has received ethical clearance from the Medical Research Ethics Committee of the Faculty of Medicine, A irlangga University, Surabaya No. 193/EC/KEPK/FKUA/2018. Rats were obtained from the Experimental Animal Unit of the Biochemistry Laboratory, Faculty of Medicine, Airlangga University. Experimental animals were divided into three groups (each group consisted of nine rats), namely a group without induction as a negative control, a positive control group induced with $600 \mathrm{mg} / \mathrm{kg} /$ day of aspirin for nine days, and a treatment group induced with $600 \mathrm{mg} / \mathrm{kg} /$ day of aspirin for nine days and followed by tulsi leaf extract at the dose of $400 \mathrm{mg} / \mathrm{kgBW}$ for seven days. Determination of experimental animals was carried out on the $16^{\text {th }}$ day after treatment.

\section{Tulsi Leaf Ethanol Extract Preparation}

Simplicia of tulsi leaves was obtained from Condido Agro Herbal, Nongkojajar, Pasuruan. Extraction of Ocimum sanctum simplicia was carried out in the Pharmacology Laboratory, Faculty of Medicine, Airlangga University. Dry simplicia powder was put into the macerator and added with three liters of solvent ( $70 \%$ ethanol). Then, it was soaked and left for 24 hours at room temperature. Filtration was carried out to separate the macerate by using filter paper; the filtration process was repeated twice with the same type and amount of solvent. All macerate was collected and then evaporated with evaporator at \pm $50^{\circ} \mathrm{C}$ until thick extract was obtained (7).

\section{Gastritis Induction and Extract Administration}

Gastritis induction was carried out to the positive control group and the treatment group by administering aspirin at a dose of $600 \mathrm{mg} / \mathrm{kg} /$ day for nine days using a feeding tube. Before administering aspirin, rats fasted for 2-3 hours. On the $10^{\text {th }}$ day to the $16^{\text {th }}$ day, the treatment group was given Ocimum sanctum leaf extract at a dose of 400 $\mathrm{mg} / \mathrm{kgBW} /$ day, while the treatment group was given standard feed and distilled water. In previous studies, the administration of Ocimum sanctum leaf extract at a dose of $400 \mathrm{mg} / \mathrm{kgBW}$ had significant effect against NSAIDinduced gastric ulcer (8).

\section{Gastric Examination}

The gastric macroscopic examination was carried out by gastric surgical of the rats that had been treated. Before surgery, the rat was fasted for 5 hours and anesthetized using ether. The rat gastric was taken by incision on the 5 $\mathrm{mm}$ superior gastroesophageal sphincter and $5 \mathrm{~mm}$ distally from the gastric pylori sphincter and then washed using $0.9 \% \mathrm{NaCl}$ solution. After surgery, the organs were fixed by immersing them in pots containing $10 \%$ formalin. The formalin immersion was done for 24 hours. Then, paraffin blocks were made by hematoxylin and eosin staining in the Anatomical Pathology Laboratory, Faculty of Medicine, Airlangga University for histopathological examination using a binocular light microscope with 400x magnification in five visual field. The evaluation was done by counting the number of PMN inflammatory cells infiltration in the mucosal and submucosa layer, and conducting a comparison to each group.

\section{RESULTS}

The results of the histopathological evaluation of gastritis by calculating the mean of PMN inflammatory cell infiltration for each group are listed in Table 1.

Table 1. Average values \pm standard deviations in the number of PMN inflammatory cells

\begin{tabular}{llll}
\hline No. & \multicolumn{1}{c}{ Group } & N & Mean \pm SD \\
\hline 1. & $\begin{array}{l}\text { Group without induction } \\
\text { (negative control) }\end{array}$ & 9 & $20.89 \pm 3.72^{\mathrm{a}}$ \\
2. & $\begin{array}{l}\text { Group of Aspirin } 600 \mathrm{mg} / \mathrm{kgBW} \\
\text { (positive control) }\end{array}$ & 9 & $32.78 \pm 7.66^{\mathrm{b}}$ \\
3. & $\begin{array}{l}\text { Group of Aspirin } 600 \mathrm{mg} / \mathrm{kgBW}+ \\
\text { Ocimum sanctum leaf extract } \\
\text { (treatment group) }\end{array}$ & 9 & $13.67 \pm 4.33^{\mathrm{c}}$ \\
\hline
\end{tabular}

Note: Different letters show significant differences $(P<0.05)$ 
There were differences in the number of inflammatory cells infiltration among the three groups. The average number of inflammatory cells infiltration was the highest in the positive control group, the group induced by 400 $\mathrm{mg} / \mathrm{kgBW}$ aspirin and given distilled water, while the lowest number of infiltration of inflammatory cells was in the treatment group induced by $400 \mathrm{mg} / \mathrm{kgBW}$ aspirin and given $600 \mathrm{mg} / \mathrm{kgBW}$ Ocimum sanctum leaf extract. Based on the results of statistical analysis, the average number of inflammatory cells infiltration in the gastric tissue of the treatment group showed a significant $(P<0.05)$ decrease compared to the positive and negative control groups.

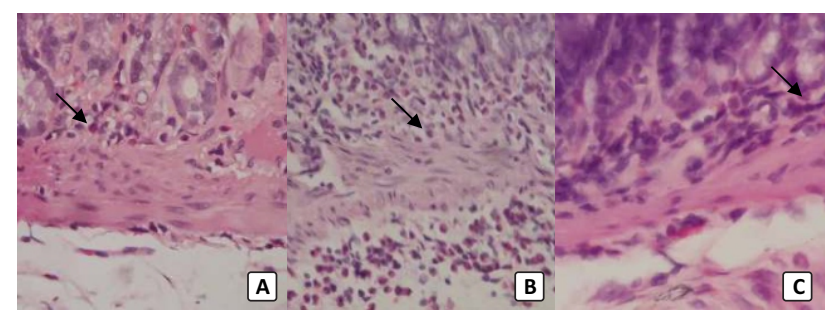

Figure 1. Histopathological image of inflammatory cells

Note: infiltration in the negative control group (A), the positive control group (B) and the treatment group (C). HE staining 400x magnification. Black arrow $=$ PMN inflammatory cells.

\section{DISCUSSION}

Aspirin induction was carried out in the positive control group and the treatment group for nine days at a dose of $600 \mathrm{mg} / \mathrm{kgBW}$. In a previous study, induction of aspirin 600 $\mathrm{mg} / \mathrm{kgBW}$ for three days caused damage to the gastric mucosa (9). Histopathological features in this group showed bleeding, edema, and PMN inflammatory cells infiltration. PMN inflammatory cells infiltration in this group showed the highest number with a significant difference. This showed that aspirin administration at a dose of $600 \mathrm{mg} / \mathrm{kgBW}$ for nine days causes inflammation in the gastric, which is characterized by an increase in inflammatory cells infiltration. The presence of neutrophils above the basement membrane, especially in direct contact with epithelial cells, is abnormal and indicates active inflammation (10). PMN inflammatory cells are an indicator of acute and active inflammation of the stomach (11). In previous studies, administration of aspirin caused acute superficial gastritis characterized by edema of the mucosal layer, capillaries dilatation and infiltration of neutrophil inflammatory cells in mucosal layer (12). Aspirin induction causes gastritis because there is an imbalance between aggressive factors and defensive factors in the stomach. Aspirin inhibits cyclooxygenase (COX) irreversibly. Inhibition of COX-1 leads to decreased mucosal prostaglandins which play a critical role in maintaining gastric mucosal defense system. In addition, aspirin could cause injury to the epithelial lining of the gastric mucosa through local mechanisms due to diffusion to the cytoplasm of epithelial cells. Aspirin is trapped and accumulated into the epithelial cells, then causes cellular injury. Mitochondria is the primary target of trapped

\section{BIBLIOGRAPHY}

1. Rugge M, Pennelli G, Pilozzi E, et al. Gastritis: The Histology Report. Digestive and Liver Disease. 2011; aspirin intracellular. It leads to the release of reactive oxygen species (ROS) such as superoxide and hydrogen peroxide thereby activating caspase 9 , caspase 3 and cellular lipid peroxidation that causes cellular apoptosis and subsequent mucosal damages (13).

The results of this study indicate that the group induced with $600 \mathrm{mg} / \mathrm{kgBW}$ aspirin for nine days and given the Ocimum sanctum leaf extract $400 \mathrm{mg} / \mathrm{kgBW}$ for seven days had the least number of inflammatory cells than the other groups. This proved that the administration of Ocimum sanctum leaf extract can reduce the degree of inflammation due to a decrease in the number of inflammatory cells in the stomach of aspirin-induced mice. Another study proved Ocimum sanctum had a significant effect against NSAID-induced gastric ulcer due to its 5lipoxygenase inhibitory effect, mucoprotective activity and antisecretory effect (8). Recently studies also had confirmed its efficacy against gastric ulcer by increasing glutathione peroxidase and catalase to prevent oxidative stress (14). Saponin content can reduce the secretion of histamine by inhibiting histidine decarboxylase, so there is a decrease in the acid secretion, which is an aggressive factor in the stomach. The suppression of stomach acid secretions is a key therapeutic target for gastritis (15).

Drugs that are approved by the FDA for the treatment and prevention of gastric ulcers due to NSAIDs are drugs that suppress aggressive factors by inhibiting gastric acid secretion (16). Flavonoids are among the cytoprotective materials of gastric mucosa. These active compounds are able to stimulate mucous, bicarbonate, and prostaglandin secretion and counteract with the deteriorating effects of reactive oxidants in gastrointestinal lumen (17). Flavonoid compound can act as radical scavengers because free radicals play an important role in the inflammation pathogenesis of aspirin (18). It will decrease mucosal damage, cell apoptosis and vascular permeability. Phenol compounds in Ocimum sanctum can reduce the production of pro-inflammatory cytokines such as IL-1 $\beta$, NF-KB and IL-8 which are the chemoattractant of inflammatory cells essential in the development of mucosal damage $(13,19,20)$. It also stimulates prostaglandin that play a critical role in maintaining gastric mucosal defense system. The enhancement of prostaglandin leads to gastritis healing because it inhibits gastric acid secretion, increases mucus and bicarbonate secretion, increases cell proliferation, and increases mucosal blood flow $(17,21)$.

This study concluded that the administration of Ocimum sanctum leaf ethanol extract at a dose of $400 \mathrm{mg} / \mathrm{kgBW}$ for seven days could reduce the degree of inflammatory gastritis because a decrease appeared in the number of PMN inflammatory cells in the gastric of rats induced by $600 \mathrm{mg} / \mathrm{kgBW}$ aspirin for nine days.

\section{ACKNOWLEDGMENT}

The authors thank the Department of Anatomical Pathology, Department of Biochemistry of Experimental Animal Unit, and Department of Pharmacology, Faculty of Medicine Airlangga University for facilitating this research.
2. Selviana BY. Effect of Coffee and Stress with the Incidence of Gastritis. Medical Journal of Lampung 
University. 2015; 4(2): 1-5.

3. Sipponen P and Maaroos HI. Chronic Gastritis. Scandinavian Journal of Gastroenterology. 2015; 50(6): 657-667.

4. Bi WP, Man HB, and Man MQ. Efficacy and Safety of Herbal Medicines in Treating Gastric Ulcer: A Review. World Journal Gastroenterol. 2014; 20(45): 17020-17028.

5. Pattanayak P, Behera P, Das D and Panda S. Ocimum sanctum Linn. A Reservoir Plant for Therapeutic Applications: An Overview. Pharmacognosy Reviews. 2010; 4(7): 95-105.

6. Siva M, Shanmugam KR, Shanmugam B, Venkata SG, Ravi S, Sathyavelu RK, and Mallikarjuna K. Ocimum sanctum: A Review on The Pharmacological Properties. International Journal of Basic and Clinical Pharmacology. 2016; 5(3): 558-565.

7. Oktavia S, Arifin H, and Irawati R. Pengaruh Ekstrak Etanol Daun Kemangi (Ocimum sanctum L.) terhadap $\mathrm{pH}$ dan Tukak Lambung pada Tikus Putih Jantan. Jurnal Farmasi Higea. 2015; 7(2): 139-151.

8. Mirje MM and Zaman SU. Evaluation of the AntiUlcer Activity of Ocimum sanctum Linn (Tulsi) in Indomethacin-Induced Gastric Ulcers in Albino Rats. International Journal of Life Sciences Biotechnology and Pharma Research. 2014; 3(1): 274-279.

9. Susilawati NM, Yuliet, and Khaerati K. Aktivitas Gastroprotektif Ekstrak Etanol Daun Gedi Hijau (Abelmoschus manihot (L.) Medik) terhadap Tikus Putih Jantan (Rattus norvegicus L.) yang Diinduksi dengan Aspirin. Natural Science: Journal of Science and Technology. 2018; 5(3): 296-306.

10. Turner JR and Lingen MW. Rongga Mulut dan Saluran Cerna. Di dalam: Kumar V, Abbas AK, and Aster JC (Eds). Robbins Basic Pathology edisi 9. Philadelphia: Elsevier Saunder; 2013: p. 564-569.

11. Kayacetin S and Guresci S. What is Gastritis? What is Gastropathy? How is it Classified? Turkish Journal of Gastroenterology. 2014; 25(3): 233-247.

12. Lintong PM, Loho LL, and Anggran H. Gambaran Histopatologik Lambung Tikus Wistar setelah Diinduksi dengan Aspirin. Jurnal Biomedik. 2013; 5(1): 38-45.
13. Matsui H, Shimokawa O, Kaneko T, Nagano Y, Rai K, and Hyodo I. The Pathophysiology of Non-Steroidal Anti-Inflammatory Drug (NSAID)-Induced Mucosal Injuries in Stomach and Small Intestine. Journal of Clinical Biochemestry and Nutrition. 2011; 48(2): 107-111.

14. Kamyab AA and Eshraghian A. Anti-Inflammatory, Gastrointestinal and Hepatoprotective Effects of Ocimum sanctum Linn: An Ancient Remedy with New Application. Inflammation \& Allergy-Drug Targets. 2013;12(6):378-384.

15. Venkateswararao $\mathrm{C}$ and Venkataramana K. A Pharmacological Review on Natural Antiulcer Agents. Journal of Global Trends in Pharmaceutical Sciences. 2013; 4(3): 1118-1131.

16. Melinda $\mathrm{M}$ and Ahmad H. Efikasi Kombinasi Rebamipide dengan Lansoprazole pada Proses Penyembuhan Tukak Lambung Tikus yang Dipapar Indometasin. Jurnal Kedokteran Brawijaya. 2011; 26(3): 166-170.

17. Akhtar M, Ahmad M, Sumbul S, and Asif M. Role of Phenolic Compounds in Peptic Ulcer: An Overview. Journal of Pharmacy and Bioallied Sciences. 2011; 3(3): 361-367.

18. Singh N, Verma P, Pandey BR, Bhalla M. Therapeutic Potential of Ocimum sanctum in Prevention and Treatment of Cancer and Exposure to Radiation: An Overview. International Journal of Pharmaceutical Sciences and Drug Research. 2012; 4(2): 97-104.

19. Hemalatha R, Babu K, Karthik M, Ramesh R, Kumar $\mathrm{BD}$, and Kumar PU. Immunomodulatory Activity and Th1/Th2 Cytokine Response of Ocimum sanctum in Myelosuppressed Swiss Albino Mice. Trends in Medical Research. 2012; 6(1): 23-31.

20. Kim Y, Seo JH, and Kim H. B-Carotene and Lutein Inhibit Hydrogen Peroxide-Induced Activation of NF$\kappa B$ and IL-8 Expression in Gastric Epithelial AGS Cells. Journal of Nutritional Science and Vitaminology. 2011; 57(3): 216-223.

21. Bjarnason I, Scarpignato C, Holmgren E, Olszewski M, Rainsford K, and Lanas A. Mechanisms of Damage to the Gastrointestinal Tract from Nonsteroidal AntiInflammatory Drugs. Gastroenterology. 2018; 154(3): 500-514 